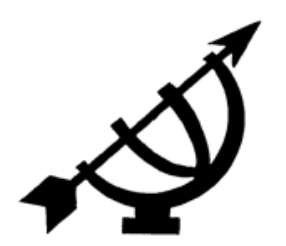

\title{
A Christian mission of glocal culture within riven societies in God's world
}

\author{
C.G. Seerveld \\ Philosophical Aesthetics \\ Institute for Christian Studies \\ Toronto \\ Ontario M5T 1R4 \\ CANADA \\ E-mail: calvins@icscanada.edu
}

\section{Abstract \\ A Christian mission of glocal culture within riven societies in God's world}

Globalisation today seems to be an implacable force at work trying to homogenise world cultures into the same format. Huntington's well-known thesis sees a clash coming between Christian Western civilisation and the rest of the world.

This article argues against Huntington that civilised cultures with different identities have comparable structural features. Because contrary cultures are all human constructs with good and bad mixed in, they can, like human relatives, learn from and correct one another rather than demonise others.

It is posited that the deepest antagonism disturbing the world is not a Christian West versus the rest, but is largely the struggle between two tyrannical ideologies: a post-Christian capitalistic secularism and a theocratic fundamentalism. A biblical Christian mission of glocal culture formation (global awareness and local action) is offered as an alternative vision for our worsening dilemma.

This biblically-rooted diaconal way to be redemptively busy in salvaging cultural activity proffers concrete hope. The life work of Bennie van der Walt is cited as an example, and a few illustrations of glocal artistry provide evidence that such a Christian mission can be deed as well as talk. 


\section{Opsomming}

\section{'n Christelike missie van glokale kultuur binne gebroke samelewings in God se wêreld}

Globalisering blyk 'n onverbiddelike krag te wees wat wêreldkulture homogeniseer tot dieselfde formaat. Huntington se welbekende hipotese voorspel 'n botsing tussen die Westerse Christelike beskawing en die res van die wêreld.

Hierdie artikel argumenteer teen die siening van Huntington dat beskaafde kulture met verskillende identiteite vergelykbare strukturele eienskappe besit. Omdat teenoorstaande kulture menslike samestellings is, met goeie en slegte eienskappe, kan hulle, soos 'n familie, by mekaar leer en mekaar reghelp, eerder as om mekaar te benadeel.

Dit word hier gestel dat die diepste vyandigheid wat die wêreld bedreig nie dié van die Christelike Weste teen die res is nie, maar grootliks die stryd tussen twee tiranniese ideologieë is, naamlik post-Christelike kapitalistiese sekularisme en 'n teokratiese fundamentalisme. 'n Bybels-Christelike missie van glokale kultuurvorming (globale bewustheid en lokale aksie) word aangebied as 'n alternatiewe visie vir hierdie verslegtende dilemma.

Die Bybels-gefundeerde diakonale manier om bevrydend besig te wees met die bewaring van kuturele aktiwiteite, bied konkrete hoop. Die lewenstaak van Bennie van der Walt word as voorbeeld hiervan voorgehou en 'n paar voorbeelde van glokale kuns voorsien die bewyse dat sodanige Christelike missie woorde sowel as dade kan wees.

\section{Foreword}

It is with gratitude to Bennie van der Walt for his and Hannetjie's long years of service in bringing good news to bear upon crosscultural matters in the continent of Africa that I chime in with these reflections on our task to give away any knowledge we may have for the healing of the nations still to come (Rev. 22:2). Although my habitat is North America and Europe, the current reality of "globalisation" tends to face us all with problems similar to the ones treated in When African and western cultures meet - from confrontation to appreciation (2006), and in Transforming power: challenging contemporary secular society (2007). In this article I put forward an outlook I have called a "glocal" approach, as an orientation not only to critique our worldwide troubles, but also as a redemptive way to pick up our human task in a post-Christian age in God's world. Bennie van der Walt, as I know and read him, has in his teaching 
and philosophical enterprise practised listening to varied ethnic Christian voices in nearby countries, and has also been serving whoever is within earshot with The liberating message: a Christian worldview for Africa (1994) - precisely what I mean by "glocal" activity.

\section{Our historical setting: a global outlook vs globalisation of culture}

The biblical perspective, I believe, charters a global outlook and cultivating reach, since this whole world belongs to God who created all creatures. Every child in need, anywhere, is my neighbour (Luke 10:25-37), and our inescapable deep human vocation is to be responsible for instituting shalom around us, wherever we call home, with whatever gifts we have. But globalisation, as I understand it, is an idolisation of global purview and tends to disregard, override or sidestep other pertinent geographic and societal realities, as if they are unimportant details. The internet is a transnational globalised system which is not so much here or there as it is nowhere in particular, but it can touchdown everywhere there is a Bill Gates terminal. Such a globalised setup, like the World Bank, seems to think wholesale, but not retail, and has a curious impersonal anonymity.

Whether globalisation is a cancerous predatory growth or a benign development with enormous potential, or both, it is critical to realise that globalisation is an utterly complex historical phenomenon, $\mathbf{1}$ not something inevitable. Globalistic institutions are human constructions, and are not to be judged apriori as an "axis of evil" or as the world's saviour. "Axis of evil" talk is always cheap, exculpating oneself and oversimplifying the troubled knot of human misery and yearning for well-being which the poor of the earth breathe, casting our human struggles into a war of "us" against "them", with "them" as the scapegoat.

Unfortunately we Christians are as "sinful" (that is, wasteful, heartless, self-righteously crooked), despite our good pious intentions, as

1 UN Secretary-General Kofi A. Annan (1999:27) catches the complexity well when he states:

Throughout much of the developing world, globalization is seen not as a term describing objective reality, but as an ideology of predatory capitalism. ... Globalization is presented as a foreign invasion that will destroy local cultures, regional tastes, and national traditions. ... In ... reaction, globalization is made the scapegoat of the ills which more often have domestic roots of a political nature. 
those who serve lords other than Jesus Christ. That fact of fallible and sometimes perverse Christian activity is partially why globalisation is an incredibly complex matter, fraught with a living history of mixed good and evil that we existentially inhabit and are called upon to reform, to move into more normative channels, so that we humans may be blessed throughout the world rather than cursed.

\section{The historical persistence of different cultural identities}

Why is there such turmoil at large in the past decades, despite the strong push to homogenise the peoples of the world into one rational, globalised culture?

\subsection{Huntington's thesis on the intrinsic clash of civilisations?}

Samuel P. Huntington developed his provocative thesis (1993) on "The clash of civilizations?" and posed that the different world civilisations he lists - the Judeo-Christian Euro-American Western, the Roman Catholic Latin American, the Russian Orthodox, the Islamic, Sub-Saharan African, Sinic-confucian, the Hindu, Buddhist, and Shinto Japanese civilisation - are each rooted in a fundamental faith which shapes a difference in culture and tradition for that civilisation. Each different world- and lifevision of the different underlying faith commitments affects that believing peoplehood's decisions on the God-human connection, the individual person and group relation, the nature of a household, the notion of rights and responsibilities, social equality and hierarchy, the role of language, artistry and machines, a proper diet, and everything else.

Huntington states that the West's attempt to shanghai the rest of the civilisations to be in its Western image - for example, every autocratic state in the world should forthwith become Jeffersonian democratic - has fueled resistence and resentment globally. Benjamin Barber captured the problem of West and the rest with his book entitled Jihad versus McWorld (1995). Huntington thinks that the Islamist and Chinese civilisations will probably join to oppose Western civilisation; so the Euro-American-Australian "West" should accept its character as a unique culture rather than pretend to be universal, and hunker down for survival in a sea of civilisational antagonisms (Huntington, 1996a:43-46; 1996b). 


\subsection{An alternative thesis: all differing cultures with an identity are nevertheless mixed human constructions}

It is very tricky for a Euro-Canadian academic not to be Eurocentric in delineating cultural identities, just as anyone who discusses "races" easily seems to become racist. Dare one ask, "Is an Afrikaner an African?". It makes a big historiographic difference whether you give priority to the statement, "Columbus discovered America", or to Aztec Moctezuma's judgment, "The Spaniards invaded our land". Once you have sat quietly in a traditional outdoor wooden Japanese toilet sheltered alone by trees and hear rain falling gently on the leaves up above - the best place to write haiku poetry, says Tanizaki (1977:3-6) - you cannot help but be shocked at the bold, brightly lit, sterilised, white porcelain bowl and chrome fixtures in an efficient sanitised Canadian bathroom.

That is, civilisations have different identities down to their details, but all cultures are human, accessible to other educable humans, who may still keep their own outlook and preferences. Also, a civilisational culture is neither monolithic nor defined by one single stereotypical feature. As Kwame Anthony Appiah (1992:ix) says: a person should know where you are coming from, what faith tradition is your primary experience, but one can participate fully in one's several coloured identities - Asanta, Ghanian, African, Christian, and Methodist. Every civilisation is hybridic. And maybe just as a genuine community can put up with dissidents too, a more sound civilisational culture will be flexible, modifiable, able to harbour variables without forfeiting its unifying ethos.

\subsection{Certain constants appear to be in the cultural contours of every civilisation}

A geopolitical location and mother tongues are basic to every particular culture. Your home territory may be oil rich and water poor, and Arabic may be considered a sacred language: those places and language ingredients enter into a lifestyle, and may entail wars to defend your culture's natural resources, and fatwas against blasphemy. In every culture the buck also stops somewhere on what life means and how we folks should deal with our basic sexual drives and need for security. Buddhist monks, for example, may teach the people to shun the dharma of daily enticements which may be perennial but are unreal, and your karma lies in adapting to the inscrutable koanic wheel of reincarnational drifting that does somehow afford a nirvana escape. Every culture also legitimates the way its members practise their livelihood. So the council of elders or sha- 
man prescribes or performs the rituals which bless the hunt or seeding the crop, and thus orders and sanctifies the communal endeavour.

That is, the culture, the cultivated fruits of a motley grouping of humans who belong together civilisationally mostly because they serve the same lord - lord Krishna, Buddha, Jesus Christ, the spirit of the ancestors, or follow the way of the prophet Muhammad or Confucius: all the different cultures have factors which are comparable and therefore, it seems to me, not inherently conflictual. Cultural features may be contrary, but not contradictory.

There are, moreover, apparently a couple of temporal stages many cultures normally go through, back and forth, from a rather unquestioned fixed societal setup of authority figures who are fairly directly in charge of whatever goes on in the many zones of communal life. Cultures move from such a settled, tradition-laden stasis to a more differentiated elastic setup of varied institutional authorities with specialised training. The change from an oral story-telling culture to one of literacy and written records is another significant intracultural change, and is not to change from an uncivilised society to civilised people - that is the Humanist myth of evolutionary progress. The bureaucratic scribes in a literate culture could be less humane in their civil service than a tribal elder who would be considered illiterate.

Another example: when the close knit interdependence of people who barter in a subsistence economy, whether it be a Confucian, Christian or animist culture, becomes a cash economy with money, a drastic depersonalisation of economic relationships takes place within that culture - it tends to loosen connections between people. Sometimes a decentralised culture like the European feudal system of lord and vassal, knights and castle, moves toward centralised monarchies, as if a clear integrational force was needed to keep the societal network from dissolution. Royal law replaced local and canon law, and the formation of nation states within European civilisation gradually took place.

\subsection{Quite different cultures are human relatives to one another}

Huntington (1996a) is correct in positing that an unarguable religionfaith is at the root of the various world civilisations, and such fundamental faiths usually have a jealous claim on persons. But Huntington is mistaken to hint that civilisational cultures are absolute 
in excluding others. In my judgment, since civilisational cultures are all fashioned by human creatures in the same world, their cultivations are, therefore, humanly related and, like ethnicity, relative - human relatives to one another.

When a given culture is in the throes of changing internally toward more diversified professionalisation of its facets, or struggling to hold onto an earlier or anticipated centralising faith power, their interaction with other civilisational cultures, which possibly are also at different stages of cohesion, may be stressful, even blameworthy. Relatives often fight. There is, however, no excuse on the world scene, for a civilisational Armaggedon, where one cultural community dehumanises, that is, demonises an other human cultural community. To frame cultural matters starkly as "us" against "them" is to play God, and for humans to play God is evil and deeply destructive.

\section{Differing tyrannies: capitalistic secularism and theocratic fundamentalism}

You don't have to be Hegelian to admit that in the increasing domination of Western culture over other civilisations since 1450 AD, and the current problem of borderless globalisation, Christian paternity is unmistakable. The legacy of Roman Catholic missionnaries exploring the Americas and Asia, and later Protestant denominational missions settling into Africa to plant churches, did not bring Jesus pure and simple, but dressed the church in Western attire, sanitation ("cleanliness is next to godliness"), medicine, trade, and colonial rule.

After the European Enlightenment a spirit of sapere aude (dare to know) without limits à la Faust, and after the Victorian Industrialisation powers that used the poor like fodder for machines, was all mixed into the template of "the Christian West" - it became questionable how biblical the label "Christian" is. Dachau and Auschwitz, Hiroshima and Nagazaki, are all events of global rank which happened under auspices of "the Christian West". True, the colonial empires of England, France, Italy, Belgium, Holland, Spain and Portugal collapsed between 1945 and 1975, but both the good and the bad which have germinated in one's deeds live on for three or four generations after one has departed. Today, however, "ethnic cleansing", multiple genocides, kamikaze suicide bombings born out of sheer desperate hatred, do not seem to have to take lessons from "the Christian West". 
The dangerous impasses on our hands, culturally too, cannot be solved by finding a single scapegoat. Rather, we need to consider the underlying battle going on between two major, cross-cultural principalities.

\subsection{Good capital and the post-Christian ideology of capitalism}

Capital is needed by poor people and poor countries to start up businesses and projects that generate employment and livelihoods. Capital or wealth is a good thing when it is given to ensure that economic activity can supply resources to serve the needs of people. But when capital is diverted into principally making more capital for those who manage to lend the reserve wealth, then the whole enterprise shifts into becoming capitalism. In a capitalistic system, where you have moved beyond barter, even beyond cash exchange to a credit economy, market transactions are not focused on the actual labour-intensive production of goods and services for people, but on how to increase the profit for those with wealth.

Early capitalism unfortunately breathed in the competitive ethic of a Darwinian vision: only the fittest survive. As capitalistic praxis became corporate in nature, oligarchic managers directed commercial operations in their firm to get bigger and cheaper in order to increase the competitive edge, obtain a larger market share and profit for all the stock holders. Capitalistic businesses tend to produce more and more of their product or service with a cost cutting efficiency, if possible, in order to develop a virtual monopoly in their area. Capitalists believe the market should be "free" to let those who deserve to be competitive winners, be winners, as in sports. The fact that there are few winners and many losers, and that economic war for profits cannot produce economic peace, does not faze an ideological capitalist whose one holy passion is success: the luxury, leisure, and happiness monied wealth can buy.

Consumerism - buy (on credit) what gives you pleasure - fits like a hand in the glove of capitalism, which has come to be synonymous with Western civilisation. The trouble is, as capitalism goes global, the circle of losers becomes greater. It is as if the "working poor" captives and undernourished children in Western cities, often unacknowledged by economic planners, are exported around the world along with the "labour-saving" Western technical devices of aid, damning even more of the two-thirds world populaces to excruciating, slow-poisoning, killing poverty (Rifkin, 1995: 128-140). The ironic retribution upon the free-wheeling Western capitalism for 
its Midas power to commodify whatever it touches - "every man has his price" - is the desperate attempt by millions of impoverished people to migrate en masse to "the Christian West" for just a little piece of the apple pie, which no-holds-barred capitalism preaches it bakes daily.

The worst thing about such globalised capitalism is that its allure is driven by a secularist faith which pretends to be "Christian", promoting freedom, although it is devoutly post-Christian, if not antiChristian, in its covetous spirit of do-it-for-yourself-at-the-expenseof-others. This unholy spirit is incorporated in the systemic sacrifice of the economically weak to the economically stronger, which the law of capitalism exacts. The benign civil religion of America - the melting-pot e pluribus unum - which privatises any faith except the common faith espoused by John Dewey of entrepreneurial democratic pragmatism, covers the capitalistic ruthlessness with a veil of choice: feel free to choose for or against this (American) way and standard of life, and may the devil take the hindmost. That ploy, however, formulates the egregious secularisation of the biblical Christian faith, because what is central to the Bible - "serve God by loving and upholding your neighbour!" - is made peripheral, a private affair. And what is peripheral or even wrong in following Jesus Christ - "look out first for number one!" - is made central to one's concern, the crux of legitimate public action. Actually it might be more honest to print on the backside of US dollar bills, "In free trade we trust".

\subsection{Fundamental faith and Islamic fundamentalism}

There are, however, millions in the world who find the covert tyranny of post-Christian capitalistic secularism insufferable. Since they religiously trust in God, Allàhu akbar, God's special channel of grace, the Prophet Muhammad (c. 570-632 AD), they know assuredly that Allah's dictated revelation and the Prophet as uswa hasana (the beautiful model for living) specifies the blessed way for life and for death. The Qur'an with the sunnah command and prohibit exactly what God's servants must do. Why should we Muslims ("the submissive ones"), ask the followers of Muhammad, and others who together make up $85 \%$ of the world population, kowtow to this $15 \%$ elite who teach rapacious greed, promote flagrant immoralities, idolise a fickle capital market relativism, and treat us as ingénues they sold Indians alcohol and guns for furs and land; now they try to buy our soul with Hollywood films and obsolescent weapons to get oil. 
We believe human life holds together and should not be split into sacred and secular pieces. Faith is not a little private matter, but faith-obedience is to be fully public, embodied in law (shariah), politically acknowledged and, if necessary, supported by military means. Nobody has the right to undermine the fundamentals of our faith and subject us as Islamic nations with a theocratic tradition of clerics and mullahs to a Secularism that reduces human life to a godless technocratic regime with religious nomads drifting aimlessly around for the next fix or curious internet fad ...

Millions of humans hold to this position.

Islamist fundamentalism rooted in the radical Muslim philosopher Sayyid Qutb's thought - he was executed in Egypt by Nasser in 1966; Sayyid's brother probably taught Osama bin Laden - found in the massive commentary (Qutb, 1999), lays the groundwork for a theocratic rule which assumes a caliph who, like the Roman Catholic pope in the Vatican state, would rule the dispersed nation - in Iran, Iraq, Algeria, Turkey or Indonesia - as Muhammad's successor and God's vice-regent on earth. A caliphate is political in nature, with possible global application, but is not necessarily offensively aggressive, except in defense of the faith. 2

\subsection{Economic and political tyrannies together delineate the cultural climate we inhabit}

The capitalist secularism I have tried to delineate, epitomised, for example, in recent American governmental practice, is economic in nature, is exercised globally and is vigorously aggressive commercially, with near political weight, co-opting much opposition, but is not always able to control the "enronic" outcomes.

When economic measures go tyrannical based on human greed, the materialistic menace produces the misery of great poverty - women, children and men destitute of home and food and even hope. When a political setup goes tyrannical based on human will to power, the political dictatorship's coercive might can produce henchmen and abject slaves under threat of violence, even torture. Economic despotism is different from political autocracy, but either tyranny makes for a hell of a human life. It is one sad thing to practice economic

2 Cf. Qutab, "Forging a new nation" (1999, 1:127-129), and "No compulsion in religion" (1999, 1:324-330). 
tyranny, but it may be even worse, I dare say, to act like a political bully, because military intervention and destruction of human societal life is more ruinous, by instilling lawless fear, than the terrible pain of economic helplessness.

It has seemed as if the government of the USA in the recent past has been fusing the authoritarian capitalistic global market practices it spearheads with a revivalist political agenda to match. The old American Monroe Doctrine (1823) declared to the world: "We, the United States of America, are in charge of this Western American hemisphere - stay away!" The new George Bush Jr. Doctrine (2002) went global: "There must be a regime change in Iraq. The United States is authorized to launch pre-emptive military strikes when it deems fit" (cf. United States of America, 2002: article 5, p. 13-16). US Defense Secretary Donald Rumsfeld is reported to have said after Iraq was invaded, "We did not come here to set up a theocracy!" Suppose, however, that Hussein's secular Baath Party ruling with a Sunni Muslim minority is out of working order, and a fundamentalist Shi'ite majority of Iraqi votes for theocratic Muslim rule. When something close to that was about to happen in Algeria with the Islamic Salvation Front (1991), a military junta disallowed the election in 1992, and the US government painfully tried to keep its options open. Political democracy is only good when its exported version gives certain predetermined results (Quandt, 1999; 2002).

It seems to me that the United States of America has thought its particular political tenets and well-intentioned actions of manifest destiny to incarnate God's will on earth and to be universal, sovereign, beyond international law. And the former President Bush's "axis of evil" mindset is precisely the same thought pattern which informed Ayatollah Khomeini's "the great Satan" discourse: they just pick different enemies who have to be annihilated. That is the real clash on our hands, not between civilisations, as Huntington supposed, but between oversimplifying fundamentalisms. This is the capitalistic secularism into which various Asian civilisations are inscribing their Hindu, Confucian, Buddhist, Shinto, Jewish and traditional beliefs, because you cannot buy into "modern" technology and weaponry without becoming secularised. The capitalistic (multideity or godless) secularism swerving into American political democratistic fundamentalism is diametrically at odds with the godly theocratic fundamentalism which is being cornered to defend its very identity and the existence of presecularised life true to Muhammad, without Islam's having the fire power to match mighty America's secularism. (The USA is the number one exporter of armaments to 
the world.) So maybe it takes pure violent martyrdom for the weaker fundamentalists and Les Damnés de la terre (Fanon, 1961) to take on the stronger fundamentalists in order to inherit what will be left of the polluted earth.

\section{Glocal culture as redemptive gambit}

One wonders what could be a biblically Christian response to such a complicated, oversimplified and dangerous impasse. Evangelical Christian fundamentalists can be as unself-critically adamant in their tunnel vision as the most rigorous Shi'ite Muslim ayatollah, Israeli Zionist, or hardcore multinational corporate capitalistic bureaucrat. Ideological fundamentalists of whatever sort always have infallible knowledge of what to do: stay on the collision course you have been pursuing, even if it means the endless cycle of judgemental, vengeful retaliation.

\subsection{An obedient biblical direction}

The Old and New Testament Scriptures posit a different direction to take: give food and drink to the enemy (Prov. 25:21-22; Rom. 12:921); let your forbearance be evident (Prov. 15:1-4; Philip. 4:4-7); may merciful just-doing be the guideline for all your deeds (Micah 6:6-8; Gal. 5:25-6:2).

Given the status quo of social, economic, political and cultural affairs around the world, I think Goudzwaard (1979) is right when he says that we people need a radical change of heart, a deep inner structural reformation of the approaches we habitually take to our human problems. External tinkering, revising a few economic priorities, attending to diplomatic niceties, and inviting foreign dance and theatre troupes to our festivals, will not be truly redemptive in the long run. And by "reformation" Goudzwaard means more than have important CEOs become born-again Christians, because if the infrastructure of a corporation is geared to Mammon, no personal pieties of the head manager changes what is wrong. Our cultural, commercial and national leaders need to become conscious that our very way of governing, doing business, and fashioning culture is in the grip of powers bigger than us humans, and such principalities are evil. Insecure militarism, consumptive profiteering, overpaid "star"-vanity, seem to be infecting our defense budgets, start up enterprises, and involvement in professional sports, museum or pop 
culture. Why do so few see that believing in better and faster technology to improve our human lot is simply a superstition! 3

It has not been helpful in cultural analyses of the last few decades to demonise Saddam Hussein, George Bush, Bill Gates, McDonald Inc., or Punk Rock and the Rolling Stones. Our biblical calling is to exorcise the nameless protean legion of violence, greed and fame which are embodied in our cultural, economic and governing systems (Eph. 6:10-12).

Christ once explained to his disciples who were nonplussed that they could not heal a boy of a spirit which drove him inexplicably into catatonic silence and then into helpless paroxysms (sounds almost like the antics of the stock-market). Christ said certain evil dominations of human endeavours can only be overcome by "prayer and fasting" (cf. Mark 9:14-29, using Syrian manuscripts on verse 29). That means: would-be world reformers need to undergo both a vow of holiness and change of lifestyle. Such a challenge catches the seriousness of the Scriptural injunction to love your global neighbour. If we are serious about changing what is systemically accursed about our disintegrating "Christian Western" civilisation, we need to re-conceive our very daily praxis so that the weak will survive, the poor shall feast, and humble dedicated artists will be honoured (cf. Luke 14:7-24). That entails that perks everywhere will hit the fan.

\subsection{The task of communal glocal action}

A way to orient current global operations with biblical vision and take up a genuinely Christian mission that could get an historical toehold now rather than wait for a future millennium is to develop a

3 The radical, deep-going kind of change needed in the orientation of our leadership is noted by Goudzwaard (1979:240) who holds that "norms" have been replaced by "goals":

The idea of beginnings, of points of departure, implicit in 'principles' (Latin: principia), is replaced by that of ends, or objectives, as S.U. Zuidema pointed out. He argued that in our time beginselen (principles) have been replaced by eindselen (ends).

Also, as Gerald Vandezande (1999:32) has put it: if an economy of grace and gratitude were to replace the economicistic approach of greedy competition, economic growth would not be conceived in terms of more and bigger (the way cancer grows) for "us", but rather in terms of equitable, sustainable development which serves legitimate human needs and contributes to the environmental and societal well-being of all people 
communal consciousness of glocal culture, and follow what I indeed think is a creatural historical norm: regenerate, speciate, and diaconate in one's field of cultivating God's world (Seerveld, 1996:56-59). It is not enough to say, "Jesus is the answer. Let's pray."

It is a biblical vision that we humans inhabit God's world and, along with our environmental terrain amid its fauna and animals, we have first of all local responsibilities to our earthly and societal habitat of neighbouring creatures. Journeys and guests open us up to other traditions, places and peoples, and that is normal. This biblical vision is not idealistic, but is describing what is creaturely available and normative. Yes, the set-up is marred by stupidity and malice. But the biblical vision of interconnected peaceable creatures is not the skewed Darwinian vision of constant struggle where the winner takes all as a matter of fact, and is also not the view of a rigid, stratified world that curtails opportunities to revise relationships for deeper shalom.

It is a Christian mission for humans to bear fruit in God's world during their earthly stay of two generations or so, God willing, beginning in your own locality, branching out as you through faithful seasoning receive broader openings and tougher assignments (Matt. 25:14-30 ff., 20-23). It is not Christian to suppose you must "save the world" - that is an imperialist presumption. Christ's followers worldwide are only asked to redeem what is entrusted to them wherever they be, and to show a saintly hospitality to strangers, that is, be cosmopolitanly open and receptive, even vulnerable to what is not your particular cup of tea, and to let your own service be educated, modified, and embraced by whatever worthwhile foreign culture comes to invigorate your way.

That is what I mean by glocal culture: your deeds are neither parochially chauvinist, nor a bricolage of being nothing in particular, but you are globally aware and act locally. By global I mean you have a biblical vision of the cosmic reach of God's grace and a sure sense of what is normative in multiple areas of human culture. By local I mean you are driven to enact restorative just-doing indigenously, so that the hallowing of any community's deed at home and abroad have a homespun integrity and identity to it, albeit open to all comers (Seerveld, 2009:302-308).

\section{Pertinent examples of glocal cultural activity}

If regenerative historical activity, in whatever field, highlights rootage of human activity in the whole global setting of God's creaturely 
good world, and if specifying distinct interrelational connections facilitates normative development of human societal prospects, the diaconate mandate anchors how we humans may try to retrace our taking wrong turns and somehow undo cumulative misdeeds with a new start. The diaconal feature anchors the Christian mission in forging opportunities with local colour.

Thus glocal culture rests in the globality of a God-ordered multifaceted world and simultaneously affirms the fact that we humans are native somewhere for a certain time and should not pretend to be omnipresent masterminds. Glocal culture is a liberating project for followers of Jesus Christ who would be redemptively busy in a world society riven by ruthless fundamentalistic forces bent on making every one of us captive. Followers of Christ do not need to worry about the final outcome of our communal endeavours.

\subsection{The biblical Christian mission in the world: not narrowly ecclesial, but glocally diaconal}

It would be a pity to restrict the historical mission of Christ's followers in God's wide world to churchly activity, since Christians are meant to be faithful in worldwide glocal activity.

Christ's body at large is meant to be like communal yeast in the very texture of commercial, political, social, communicative, educational and artistic endeavours, as professionals who know how to set generous economic policy, make restorative political judgements, offer joyful cultural ideas that have a radically reconciling, forgiving, wise hope-bearing thrust. This project is precisely what Bennie van der Walt has carried out while teaching and publishing for fellow Africans from the Institute for Reformational Studies (1974-1999) when it operated at the Potchefstroom University for Christian Higher Education. The very antithesis to such embedded glocal Christian activity is to act as if your faith is a purely private prayerful matter. Such privatised faith action, it seems to me, is to betray Jesus Christ with a devotional kiss.

To think and act as if missional means acting like an evangelist or chaplain is a severely truncated vision of the believing community's task. Christians are best pictured, says the Bible, not as preaching clerics, but as being waiters and waitresses who together are found, when Christ returns, serving up unadulterated cultural food to their neighbours in God's global household (Matt. 24:45-47), including giving bread to the outcasts and God's enemies who may deserve 
anathemas, overcoming evil with good (Ps. 139:19-24; Matt. 5:3849; Rom. 12:9-21).

\subsection{Examples of glocal art-making culture illustrating the mission of Christ's body}

\section{Illustration A: Die inisiante (1987/1991)}

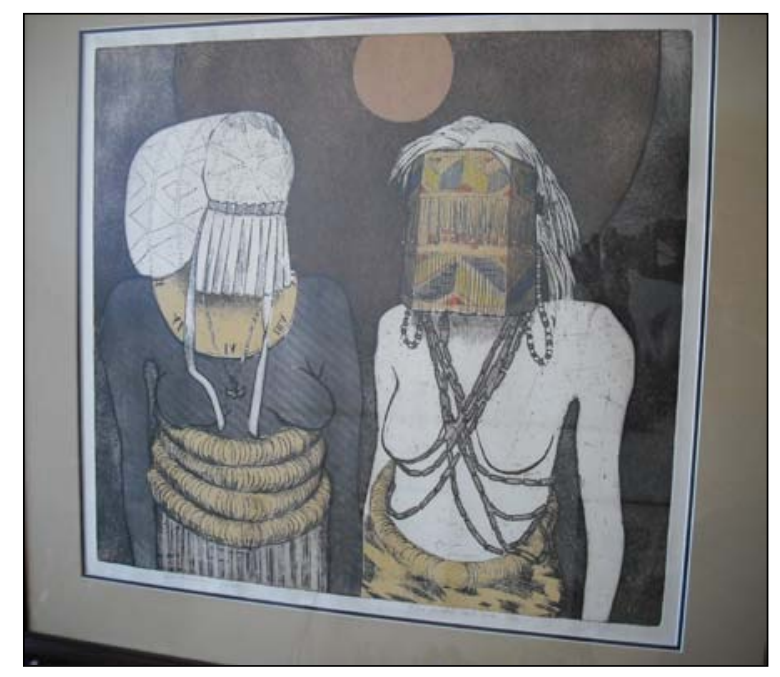

When I visited a shanty town near Potchefstroom, South Africa, in 1995, I was struck by the fact that guard towers could not obliterate the spark of laying down a green grass path in the rocky dirt as aisle to the communal outhouse one walked to in order to relieve oneself, reaching for a touch of human dignity. And more than 20 years ago South African Titia Ballot quietly explored in an engraving entitled Die inisiante (1987/1991) how women could perhaps bridge the gap of animosity between races there: the white woman wears the native beads awkwardly like chains with the fetish wrongly covering her face, while the black woman wears a Huguenot cross upside down and an Afrikaner kappie (bonnet) on backwards: we come together unhandily, but we are struggling to understand one another under the round hot bulls-eye of an unforgiving African sun. 


\section{Illustration B: Platform 1 (1992)}

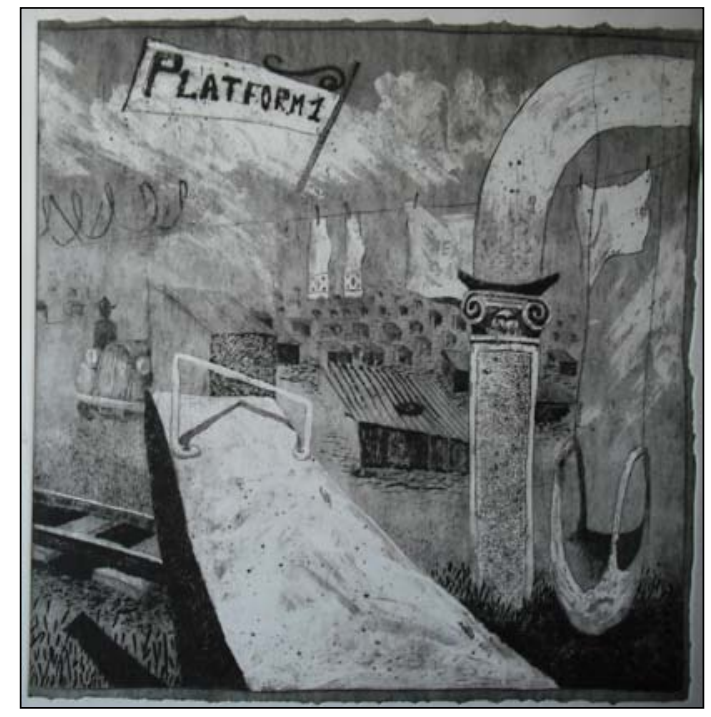

George van der Walt's large engraving, Platform 1 (1992) documented the complexity facing "the new South Africa": the shambles of a classical ancient Greek ionic column next to a cement transportation platform going nowhere, crisscrossed by a fragment of train tracks; a field of wooden coffins (instead of crosses?) stretches into the distance, attended by a lone spectator with an old fashioned car under a hint of barbed wire and billowing white clouds (or flames?) - but there is a clothes line spanning the breadth of the scene with a pair of washed socks hung up to dry, and one of the other cloths on the line looks like a white flag announcing a truce. This piece of art celebrates the homespun little realities of a person's local habitation, but puts the daily details into the global context of apartheid, a memento tire necklace, disruptive change, travel, and maybe ... a down-to-earth hope.

Illustration C: I cannot speak my language (1970)

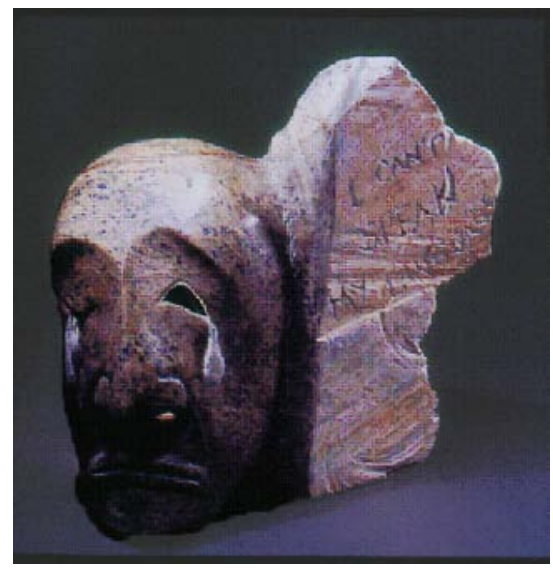


There is a sculpture by an anonymous Inuit carver, I cannot speak my language (1970s?), which has abalone mother-of-pearl tears dangling like earrings on the whole head half hewn from the block of creased stone, as if there is an overwhelming sadness to being cut from one's moorings to face the present state of affairs. After I learned that the Finnish singer Nina Astrom spends time singing in women prisons located in Russia, Scandinavia and Canada, the tears of this sculpture shone for me like diamonds. Nina gives her voice to those women locked away and forgotten by society so that the hardness, anger, and sadness, the tears, they know and have been unable to show are miraculously given a voice to cry out, "We are human too, in this abusive society!"

\section{Illustration D: Caritas (2003)}

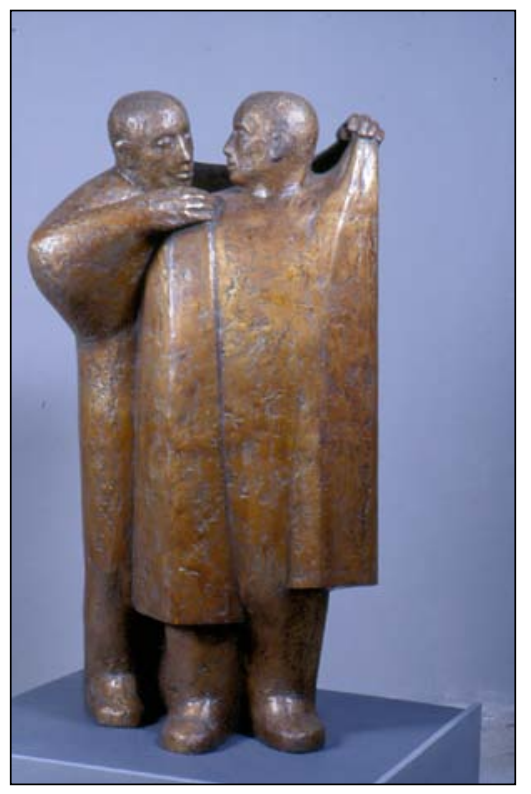

Dutch Britt Wikstrom's three-quarter life-size bronze sculpture, Caritas (2003), rests in a major hospital for cancer patients in Chicago: severe illness, almost like imprisonment, closes down your world and exposes you in your most vulnerable secrets to anyone who tries to help. The firm gentle lines and wonderful enveloping embrace of putting a cloak around a patient's shoulders makes compassion visible, tactile, the care-giver bent at the knee intimates almost a prayerful solicitude. Everything is slow motion, so basic to the timing of Caritas. And the patient's response to being patiently clothed is one of wonderful, grateful reception that itself gives strengthening in return. Exceptionally strong about this sculpture, in my judgement, is that the piece has no hospital heroics, no emergency theatrics, and it does not push the question of "Why the 
evil of sickness!?" but simply, powerfully presents a tender pas de deux tribute to the promise of mutual human care filled with unutterable thankfulness

To me such glocal artistry is deeply Christian, because it is not conceived in self-indulgence and is not practiced to get media fame, but is practised the way God meant art to be: a nuanced glocal give away bearing a breath of real hope. Sound imaginative activity and artistry, amateur or professional, will always be glocal, born out of a local habitation and sensitivity while aware of the global creatural realities that face us humans.

Whatever nationality one be, which situates you in a local habitat, as a professional artist with a biblical vision of God's creatural world, and one who is driven by the Christian mission to serve one's neighbour with the healing rule of Jesus Christ, you simply make artworks. Then you find an audience in the prisons and hospitals, next door, art galleries and out of the way places, so that the tough love you volunteer artistically, will have the impact of setting people free - free with a glimmer of the Lord's finally making human lives, society and the world at large whole (Isa. 61; Luke 4:14-21).

These few artworks give graphic voice to how I understand Bennie van der Walt as selflessly and professionally carrying out the philosophical task as a glocal educational ministry these many years. Along with a convicting vision of God's creatures worldwide and an intimate knowledge of the shaping work the Lord revealed in Jesus Christ has given us humans to embody historically such endeavours, Professor B.J. van der Walt has never shirked from being the little child of faith who loves the nearby neighbour - of whatever ethnic background and no matter what the faith-conviction. He has been giving away the bread of biblical wisdom (Eccles. 11:16) instead of the stones of arguing discontent. I pray that he and his loved ones receive a full measure of grateful return on their labours for our Lord.

\section{List of references}

ANNAN, K.A. 1999. The backlash against globalism. The futurist, 33(3):27, Mar. APPIAH, K.A. 1992. In my father's house: Africa in the philosophy of culture. New York: Oxford University Press.

FANON, F. 1961. Les damnés de la terre. Paris: Maspero.

GOUDZWAARD, B. 1979. Capitalism and progress: a diagnosis of Western society. Trans. and ed. by J. van Nuis Zylstra. Toronto: Wedge Publishing Foundation. 
HUNTINGTON, S.P. 1993. The clash of civilisations? Foreign affairs, 72(3):2249.

HUNTINGTON, S.P. 1996a. The clash of civilisations and the remaking of world order. New York: Simon \& Schuster.

HUNTINGTON, S.P. 1996b. The West not unique, not universal. Foreign affairs, 75:238-245, Nov./Dec.

UNITED STATES OF AMERICA. 2002. National security strategy. http://www.global/security.org/military/library/.../national/nss-020920.pdf Date of access: 7 Apr. 2010.

QUANDT, W.B. 1999. Algeria's election fiasco. Civil society: democratization in the Arab world, 8:90. www.ibnkhaldun.org/newsletter/1999/june/essay1. html 7 Apr. 2007.

QUANDT, W.B. 2002. US and Algeria: just flirting. Le Monde diplomatique, Jul. 2002. http://mondediplo.com/2002/07/08algeria 9 Aug. 2010.

QUTB, S. 1999. Fi ilal al Qur'an/In the shade of the Qur'an. Vol. 1: On surahs, 1-2. Trans. by M.A. Salahi \& A.A. Shamis. Leicester: The Islamic Foundation.

RIFKIN, J. 1995. The end of work: the decline of the global labor force and the dawn of the post-market era. New York: Putnam.

SEERVELD, C.G. 1996. Dooyeweerd's idea of "historical development": Christian respect for cultural diversity. Westminster theological journal, 58:41-61.

SEERVELD. C.G. 2009. Cities as a place for public artwork: a glocal approach. (In Goheen, M.W. \& Glanville, E.G., eds. The gospel and globalisation: exploring the religious roots of a globalised world. Vancouver: Regent College Publishing \& Geneva Society. p. 229-324.)

TANIZAKI, J. 1977. In praise of shadows. Trans. From Japanese by T.J. Harper \& E.G. Seidensticker. New Haven: Leete's Island Books.

VANDEZANDE, G. 1999. Justice, not just us: faith perspectives and national priorities. Ed. by M.R. vander Vennen. Toronto: Public Justice Resource Center.

\section{Key concepts:}

Christian cultural mission

diaconal artwork

globalisation

glocal culture

\section{Kernbegrippe:}

Christelike kulturele missie

diakonale kunswerk

globalisering

glokale kultuur 